\title{
Effects of wilting and additives on the ensiling quality and in vitro rumen fermentation characteristics of sudangrass silage
}

\author{
Jiang Chun Wan ${ }^{1,2}$, Kai Yun Xie ${ }^{2}$, Yu Xiang Wang ${ }^{2}$, Li Liü ${ }^{2}$, Zhu Yu ${ }^{1, *}$, and Bing Wang ${ }^{1}$
}

\footnotetext{
* Corresponding Authors: Zhu Yu Tel: +86-10-880-76292, Fax: +86-10-880-76292, E-mail: yuzhu33150@sina.com

${ }^{1}$ College of Animal Science and Technology, China Agricultural University, Beijing 100193, China

${ }^{2}$ College of Grassland and Environment

Science, Xinjiang Agricultural University,

Urumqi, 830052, China

ORCID

Jiang Chun Wan

https://orcid.org/0000-0002-2915-6979

Kai Yun Xie

https://orcid.org/0000-0003-0447-1929

Yu Xiang Wang

https://orcid.org/0000-0002-7297-9866 Li Liu

https://orcid.org/0000-0001-6278-0127

Zhu Yu

https://orcid.org/0000-0003-3271-1272

Bing Wang

https://orcid.org/0000-0003-4410-0495
}

Submitted Feb 11, 2020; Revised Mar 10, 2020; Accepted May 13, 2020
Objective: This study was conducted to investigate the effects of molasses and Lactobacillus plantarum on the ensiling quality and in vitro rumen fermentation of sudangrass silage prepared with or without wilting.

Methods: The ensiling experiment, measured with 3 replicates, was carried out according to a $2 \times 4$ (wilted stages $\times a d d i t i v e s)$ factorial treatment structure. Dry matter of the fresh $(210$ $\mathrm{g} / \mathrm{kg}$ fresh matter) or wilted (305 g/kg fresh matter) sudangrass were ensiled (packed into 5.0-L plastic jars) without additive (control) or with molasses (M), Lactobacillus plantarum (LP), or molasses + Lactobacillus plantarum $(\mathrm{M}+\mathrm{LP})$. After 60 days of ensiling, the silages were analyzed for the chemical, fermentation, and in vitro characteristics.

Results: After 60 days of ensiling, the fermentation parameters were affected by wilted, the additives and the interactions of wilted with the additives $(p<0.05)$. The $M+L P$ treatment at wilted had higher lactic acid levels and $\mathrm{V}$-score $(\mathrm{p}<0.05)$ but lower $\mathrm{pH}$ values and butyric acid concentrations than the other treatments. In comparison with sudangrass before ensiling, after ensiling had lower dry matter and higher non-fibrous carbohydrate. The in vitro gas production, in vitro dry matter digestibility, in vitro crude protein digestibility, and in vitro acid fiber detergent digestibility changed under the effects of the additives. Significant interactions were observed between wilted and the additives in terms of in vitro gas production at $48 \mathrm{~h}$, asymptotic gas production, gas production rate, half time, and the average gas production rate. The total volatile fatty acid levels in the additive treatments were higher than those in the control.

Conclusion: Wilting and supplementation with molasses and Lactobacillus plantarum had the ability to improve the ensiling quality and in vitro nutrient digestibility of sudangrass silage. The M+LP treatment at wilted exhibited the strongest positive effects on silage quality and in vitro ruminal fermentation characteristics.

Keywords: Fermentative Profile; In vitro Rumen Fermentation; Wilting; Additives; Sudangrass

\section{INTRODUCTION}

Sudangrass (Sorghum sudanense (Piper) Stapf) is a major forage grass species that is widely cultivated in West China due to its high salt tolerance. Annually, more than 1,000 hectares of sudangrass are grown as a feed source. Ensiling is a good method by which sudangrass can be processed and preserved, especially in places where it always rains during the harvest period. However, the low dry matter $(\mathrm{DM})(<280 \mathrm{~g} / \mathrm{kg} \mathrm{DM})$ content of sudangrass results in poor silage quality. It has been reported that butyric acids (BA) are produced due to high moisture content during the ensiling of sudangrass [1]. It is known that in low-DM concentration silage some groups of clostridia can act by converting water soluble carbohydrate (WSC) into BA. Moreover, the high moisture concentration of silage produces a higher proteolytic activity by the clostridium proteolytic group. Often the poor fermentation 
quality of any grass silage is associated with high moisture and delay in $\mathrm{pH}$ drop because of the low WSC concentration. The poor fermentation characteristics limit the utilization of sudangrass as livestock feed, thus, effective measures, such as wilting, use of acid-type additives (e.g., potassium diformate, sodium diacetate), inoculation (e.g., homofermentative lactic acid bacteria, heterofermentative lactic acid bacteria, combination inoculants containing homofermentative and heterofermentative lactic acid bacteria) and use of enzymes (e.g., cellulase, hemicellulase) should be used to improve the ensiling quality.

The key measure to determine improvement of the ensiling quality is mainly lactic acid production during ensiling. Molasses is used extensively as a fermentation stimulant since this material provides fermentable substrates for lactic acid bacteria (LAB) [2]. Zhang et al [3] found that Urtica cannabina treated with molasses at either $4 \%$ or $8 \%$ produced wellpreserved silage with a faster acidification rate and greater lactic acid (LA) levels than untreated silages. Kang et al [4] found that treatment of four-month cassava top with $2 \%$ molasses improved the silage quality and the in vitro rumen fermentation efficiency. Supplementation with homo-LAB leads to efficient WSC utilization, resulting in rapid reduction of $\mathrm{pH}$ and decreased nutrient loss. Many researchers $[5,6]$ have focused on improvement of the fermentation quality of silage via inoculation with Lactobacillus plantarum (L. plantarum) because this microbe produces sufficient LA for rapid reduction of the $\mathrm{pH}$. Wilting is an efficient, widely used pretreatment method in ensiling, with the ability to decrease plant protease activity, clostridial growth, and the amount of silage effluent, as well as to increase the sugar concentrations in crops, thereby improving the nutritional quality of the silage [7].

In vitro gas production (GP) is well-accepted technique for measurement of the ruminal degradation rates of feedstuffs. In vitro studies have detected increased microbial biomass yields caused by inoculation of silages with molasses and $L$. plantarum with different GP levels and total volatile fatty acid (VFA) concentrations [5]. A recent study demonstrated that inoculation of silage with L. plantarum elicits different in vitro responses [6]. In addition, the lag time of feedstuff has been reported to be affected by the rumen liquor. Consequently, in vitro GP and DM digestibility might also be affected. Either wilting or additives could improve fermentation quality and reduce nutrient loss during ensiling. To date, research on ensiling quality and in vitro ruminal fermentation characteristics of sudangrass silage with both wilting and additives is lacking, and whether the wilting and additives have positive effects on in vitro GP and DM digestibility on sudangrass silage is not clear. Thus, the aim of this study was to determine the effect of wilting and supplementation with molasses and $L$. plantarum on the quality of sudangrass silage.

\section{MATERIALS AND METHODS}

\section{Sudangrass harvest}

Pure sudangrass (Sorghum sudanense (Piper) Stapf) was grown in experimental plots at Sanping practice base in Xinjiang Agricultural University (latitude $43^{\circ} 54^{\prime} \mathrm{N}$, longitude $87^{\circ} 19^{\prime} \mathrm{E}$ ), which is situated in Xinjiang province, China, from April to July 2019, using Xinsu sudangrass variety No. 3 (Ministry of Education Key Laboratory for Western Arid Region Grassland Resources and Ecology, Xinjiang, China). Triplicate randomized experimental plots were used, each plot with an area of $5 \mathrm{~m} \times 10 \mathrm{~m}$. Approximately $45 \mathrm{~kg} / \mathrm{hm}^{2}$ of cow manure fertiliser being applied during the sudangrass growing. The soil type in this area is typically loamy soil and the average soil organic matter in the experimental plots was 15.6 $\mathrm{g} / \mathrm{kg}$; effective $\mathrm{N}, \mathrm{P}$, and $\mathrm{K}$ in the soil were $91.3,23.7$, and $103.1 \mathrm{mg} / \mathrm{kg}$, respectively. The sudangrass was sown in 25 April 2019 at a seeding rate of $105 \mathrm{~kg} / \mathrm{hm}^{2}$ in each block and the first-cut sudangrass was manually harvested in 6 July 2019 by sickle at the early-heading stage from three replicated plots. The plant materials were chopped to a 20 $\mathrm{mm}$ nominal length and then sampled in triplicate and stored at $-20^{\circ} \mathrm{C}$ prior to chemical analyses.

\section{Experimental design and silage preparation}

The ensiling experiment was carried out according to a $2 \times 4$ (wilted stages $\times$ additives) factorial treatment structure. The sudangrass was direct wilted at the field in the sun for $8 \mathrm{~h}$ (direct-cut sudangrass) and turning of the forage every $2 \mathrm{~h}$. The factors associated with the wilted stage were fresh or wilted $(8 \mathrm{~h})$, and the 4 additive treatments were i) no additive (control, CK); ii) molasses (M) (Tianshun Bioengineering Co., Ltd., Urumqi, China) applied at 5\% fresh weight (FW); iii) L. plantarum (LP) (strain 10474, China General Microbiological Culture Collection Center, Beijing, China) applied at $1 \times 10^{5}$ colony forming units (CFU)/g FW; iv) molasses (M, Tianshun Bioengineering Co., Ltd, Urumqi, China) applied at 5\% FW + L. plantarum (LP, strain 10474, China General Microbiological Culture Collection Center, Beijing, China) applied at $1 \times 10^{5} \mathrm{CFU} / \mathrm{g}$ FW. Based on the manufacturer's information, the molasses contained $45.2 \%$ moisture, $59.2 \%$ total sugar DM, 38.4\% sucrose and $12.4 \%$ reducing sugars. According to the set additive amount, the molasses, $L$. plantarum, and molasses $+L$. plantarum were diluted to $0.5 \mathrm{~L}$ with water, respectively. The same amount of water was added to the control. The additives were diluted in deionized water and each treatment was sprayed in a fine mist on the sudangrass from each of the appropriate replicate plots separately using a hand sprayer (Sail Multipurpose sprayer, Sail Corp., Beijing, China). Hand forks were used to mix the forage from 
each treatment. The materials $(3,200 \mathrm{~g})$ were individually packed into 5.0-L plastic jars (Hewanglan Paper and Plastic Products Factory, Beijing, China) and sealed with plastic tape and caps. Each treatment stored at an ambient temperature of approximately $26.0^{\circ} \mathrm{C} \pm 3.7^{\circ} \mathrm{C}$. After 60 days of ensiling, the jars were opened and sampled; the samples were stored at $-20^{\circ} \mathrm{C}$ for subsequent chemical analysis of the $\mathrm{DM}$, crude protein $(\mathrm{CP})$, neutral detergent fiber (NDF), acid detergent fiber (ADF), ether extract (EE), ash, pH, LA, acetic acid (AA), propionic acid (PA), $\mathrm{BA}$, WSC, $\mathrm{NH}_{3}-\mathrm{N}$ (ammonia nitrogen), and in vitro batch cultures.

\section{Chemical analyses}

Following the method described by Owens et al [8], $20 \mathrm{~g}$ of each fresh silage sample was homogenized in a blender with $180 \mathrm{~mL}$ of distilled water for $1 \mathrm{~min}$ and then filtered through four layers of cheesecloth. Then, the $\mathrm{pH}$ of the filtrate was measured immediately using a glass electrode $\mathrm{pH}$ meter (PHS-3C, INESA Scientific Instrument Co., Ltd., Shanghai, China). The DM content was determined by oven drying at $60^{\circ} \mathrm{C}$ for $48 \mathrm{~h}$. The DM recovery was calculated as (1 - [(ensiled forage DM - forage DM at silo opening)/ensiled forage $\mathrm{DM}]) \times 100$. NDF and ADF levels were measured as described by Mertens [9]. The ash content was determined by ignition at $550^{\circ} \mathrm{C}$ for $3 \mathrm{~h}$, and the EE was examined according to the methods described by the Association of Official Analytical Chemists (AOAC) [10]. The buffering capacity (BC) of the fresh matter (FM) was determined by titration [11]. The WSC levels were determined using the anthrone method [12]. The nitrogen $(\mathrm{N})$ content was analyzed according to the methods of the AOAC [10], and the CP content was estimated by multiplying the $\mathrm{N}$ content by 6.25 .

The $\mathrm{pH}$ values of the in vitro ruminal fluid samples were measured using a pH meter as described above. The $\mathrm{NH}_{3}-\mathrm{N}$ concentrations in the silage were determined by the method described by Broderick and Kang [13] and expressed as g/kg of total nitrogen (TN). The levels of organic acids, including lactic acid, $\mathrm{AA}, \mathrm{PA}$, and $\mathrm{BA}$, in the silage and in vitro ruminal fluid samples were determined by high-performance liquid chromatography (LC-20A; Shimadzu, Tokyo, Japan). The analytical conditions were as follows: column, Shodex RSpak KC-811S-DVB gel C $(8.0 \mathrm{~mm} \times 30 \mathrm{~cm}$, Shimadzu, Japan); oven temperature, $50^{\circ} \mathrm{C}$; mobile phase, $3 \mathrm{mmol} / \mathrm{L} \mathrm{HClO} 4$; flow rate, $1.0 \mathrm{~mL} / \mathrm{min}$; injection volume $5 \mu \mathrm{L}$; detector, SPDM20AVP (Shimadzu, Japan). To assess the ensiling quality, the V-score from the $\mathrm{NH}_{3}-\mathrm{N}$ and VFA concentrations were calculated [14].

\section{Microbiological analyses}

The LAB counts were determined using MRS agar and violet red bile agar after incubation at $30^{\circ} \mathrm{C}$ for 2 days. Aerobic bacterial counts were determined after growth on nutrient agar at $37^{\circ} \mathrm{C}$ for 3 days under aerobic conditions. All yeasts and moulds were enumerated on spread plates containing yeast extract/peptone/dextrose agar and salt Czapek Dox agar, respectively, after incubation at $28^{\circ} \mathrm{C}$ for 3 to 5 days. The four media were obtained from Beijing Aoboxing Biotech (Beijing, China). All microbial data were transformed to $\log 10$ values and presented on a wet weight basis.

\section{In vitro rumen fermentation}

Silage samples were oven-dried at $65^{\circ} \mathrm{C}$, ground, and sieved through a $1-\mathrm{mm}$ screen. The dried silages $(500 \mathrm{mg}$ ) were weighed into $120-\mathrm{mL}$ glass bottles with butyl rubber stoppers and Hungate's screw caps. Five bottles per silage sample and 30 bottles per treatment were arranged. Fifty milliliters of a freshly prepared buffer solution ( $\mathrm{pH} 6.85)$ and $25 \mathrm{~mL}$ of filtered rumen fluid collected from three rumen-fistulated lactating Holstein dairy cows $(423 \pm 18 \mathrm{~kg}$ body weight, the animals were restricted to a supply of the same amount of a standardized diet containing $5.0 \mathrm{~kg}$ of alfalfa hay, $2.0 \mathrm{~kg}$ of wheat straw and $6.0 \mathrm{~kg}$ of commercial concentrate supplement per day) were added to the bottles before the morning feeding. The bottles were purged anaerobically with $\mathrm{CO}_{2}$ for $5 \mathrm{~s}$, sealed with the butyl rubber stopper and Hungate's screw caps, and individually connected with medical plastic infusion pipes to gas inlets of an automated trace gas recording system to continuously record cumulative GP $(0,2,4,8,12$, $24,36,48 \mathrm{~h}$ ). All bottles were incubated at $39^{\circ} \mathrm{C}$ for $48 \mathrm{~h}$, and the entire experiment was repeated for three runs. At the end of incubation, the culture fluids in each bottle were individually filtered with pre-weighed nylon bags $(8 \times 12 \mathrm{~cm}, 42-\mu \mathrm{m}$ pore size). The $\mathrm{pH}$ value, $\mathrm{NH}_{3}-\mathrm{N}$ content and organic acid content of the filtrate were determined according to the method described above. The bags were thoroughly rinsed and dried at $65^{\circ} \mathrm{C}$ for $48 \mathrm{~h}$ to a constant weight. The differences between DM, CP, NDF, and ADF at initial incubation and the residual DM, CP, NDF, and ADF, respectively, corrected with the blanks after incubation were calculated to determine the in vitro $\mathrm{DM}, \mathrm{CP}, \mathrm{NDF}$, and $\mathrm{ADF}$ disappearance (IVDMD, IVCPD, IVNDFD, and IVADFD, respectively) values.

\section{Biometric analysis}

The cumulative GP $(t, \mathrm{~mL} / \mathrm{g} \mathrm{DM})$ at time $(t)$ for each fermentation bottle was fitted to an exponential model [15]:

$$
\mathrm{GP}_{\mathrm{t}}=\mathrm{A}^{\prime}\left[1-\mathrm{e}^{-\mathrm{c}^{\prime}(\mathrm{t}-\mathrm{Lag})}\right]
$$

where ' $e$ ' is the base of a natural logarithm; A represents the asymptotic GP generated at a constant fractional rate $(c)$ per unit time; $t$ is the gas recording time, and Lag represents a lag time phase before commencement of GP. The average GP rate $(\mathrm{AGPR}, \mathrm{mL} / \mathrm{h}$ ) was defined as the rate between the start 
of incubation and the time at which the GP was half of its asymptotic value according to the following equation [16]:

$$
\mathrm{AGPR}=\frac{A \times c}{2 \times(\operatorname{Ln} 2+c \times \operatorname{Lag})}
$$

The ratio of non-glucogenic to glucogenic acids (NGR) was calculated as described by Orskov [17] as follows:

$$
\mathrm{NGR}=\frac{\text { Acetate }+2 \times \text { Butyrate }+ \text { Valerate }}{\text { Propionate }+ \text { Valerate }}
$$

where acetate, propionate, butyrate and valerate were expressed in molar proportions.

The fermentative characteristics, microbial counts, and in vitro and chemical compositional parameters were analyzed for significant differences via analysis of variance (ANOVA), with significance reported at a probability level of 0.05 , using the general linear model in SPSS (version 21.0, SPSS Inc., Chicago, IL, USA). All data were subjected to ANOVA using the general linear model procedure in SPSS, based on the following model:

$$
\mathrm{Y}_{\mathrm{ij}}=\mu+\mathrm{W}_{\mathrm{i}}+\mathrm{A}_{\mathrm{j}}+(\mathrm{W} \times \mathrm{A})_{\mathrm{ij}}+\mathrm{e}_{\mathrm{ij}}
$$

where $Y_{i j}$ is the response variable (e.g., GP, fermentation kinetics parameters); $\mu$ is the overall mean; $\mathrm{W}_{\mathrm{i}}$ is the wilted stage of the sudangrass ( $i=$ fresh or wilted); $A_{j}$ is the additive $(\mathrm{j}=$ control, molasses, $L$. plantarum or molasses $+L$. plantarum); $(\mathrm{W} \times \mathrm{A})_{\mathrm{ij}}$ is the interaction term between wilted and additives; and $\mathrm{e}_{\mathrm{ij}}$ is the residual error. Differences between treatment means were compared using the least square means method and Tukey's multiple comparison test. The results are reported as least square means and the associated standard errors.

\section{RESULTS}

\section{Chemical and microbial compositions of materials before ensiling}

The included as a chemical composition of the sudangrass before ensiling are presented in Table 1. The DM, ADF, and ash content of the sudangrass after wilting was higher than that fresh. In contrast, the WSC and BC content of the sudangrass after wilting was lower than that fresh. The fermentation coefficient was lower than 25 for both treatments. The number of epiphytic LAB on the sudangrass was less than $1.0 \times 10^{5}$ $\mathrm{CFU} / \mathrm{g} \mathrm{FM}$, and the number of yeast cells was approximately $1.0 \times 10^{3} \mathrm{CFU} / \mathrm{g}$ FM.

Fermentation quality of sudangrass silage after $\mathbf{6 0}$ days of ensiling

The six sudangrass silages were well preserved with additives, as indicated by the low $\mathrm{pH}$ value and $\mathrm{NH}_{3}-\mathrm{N}$ proportion and high LA content and V-score compared to the control (Table 2). The $\mathrm{pH}, \mathrm{LA}, \mathrm{AA}, \mathrm{PA}, \mathrm{BA}, \mathrm{WSC}, \mathrm{NH}_{3}-\mathrm{N}$ levels and $\mathrm{V}$-score were significantly influenced by wilted, the additives, and the interaction of wilted with the additives $(p<0.05)$. No significant interaction between wilted and additives was observed in terms of the counts of yeasts $(\mathrm{p}=0.150)$ and moulds $(\mathrm{p}=$ 0.158). The BA content was less than $5.0 \mathrm{~g} / \mathrm{kg} \mathrm{DM}$ in all the treatments except the control of the fresh. Except for the

Table 1. Chemical composition and microbial populations contents of sudangrass before ensiling

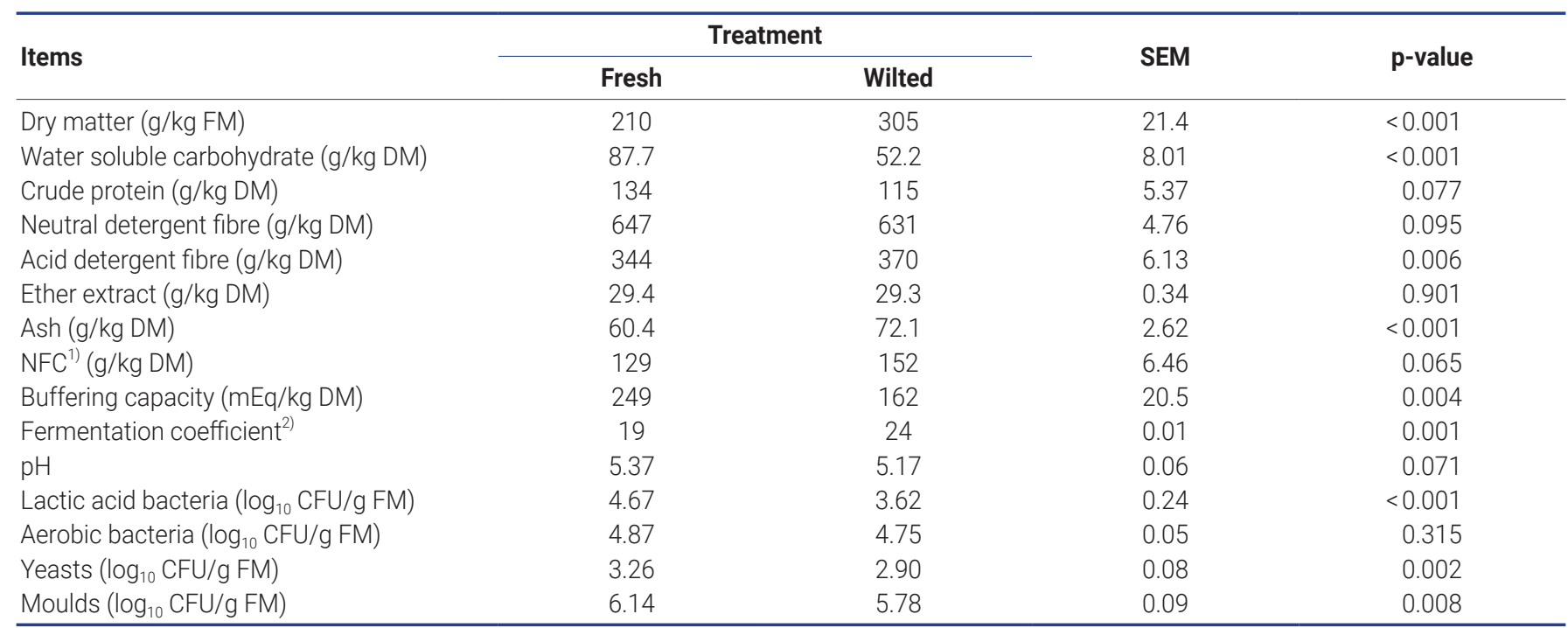

SEM, standard error of the mean; FM, fresh matter; DM, dry matter; NFC, non-fibrous carbohydrate; mEq, milligram equivalent; CFU, colony-forming units.

1) NFC = 100-CP-NDF-EE-ash.

2) Fermentation coefficient $=\mathrm{DM}(\%)+8 \mathrm{WSC} / \mathrm{BC}$. 
Table 2. Effect of wilting and additives on fermentation quality and microbial populations of sudangrass silage after $60 \mathrm{~d}$ of ensiling

\begin{tabular}{|c|c|c|c|c|c|c|c|c|c|c|c|c|}
\hline \multirow{3}{*}{ Items } & \multicolumn{8}{|c|}{ Treatments ${ }^{1)}$} & \multirow{3}{*}{ SEM } & \multirow{2}{*}{\multicolumn{3}{|c|}{$p$-value }} \\
\hline & \multicolumn{4}{|c|}{ Fresh } & \multicolumn{4}{|c|}{ Wilted } & & & & \\
\hline & CK & M & LP & $M+L P$ & CK & M & LP & $M+L P$ & & Wilted & Additives & $\begin{array}{c}\text { Wilted } \\
\text { xadditives }\end{array}$ \\
\hline $\mathrm{pH}$ & $4.81^{\mathrm{a}}$ & $4.50^{c}$ & $4.47^{c}$ & $4.36^{d}$ & $4.70^{b}$ & $4.28^{e}$ & $4.19^{f}$ & $4.06^{9}$ & 0.05 & $<0.001$ & $<0.001$ & $<0.001$ \\
\hline Lactic acid (g/kg DM) & $32.2^{f}$ & $46.2^{e}$ & $46.1^{e}$ & $50.5^{d}$ & $28.8^{9}$ & $55.1^{c}$ & $59.5^{b}$ & $66.0^{\mathrm{a}}$ & 2.59 & $<0.001$ & $<0.001$ & $<0.001$ \\
\hline Acetic acid (g/kg DM) & $22.1^{\mathrm{a}}$ & $8.68^{c}$ & $8.03^{d}$ & $6.23^{f}$ & $10.7^{b}$ & $7.14^{e}$ & $5.00^{9}$ & $4.69^{9}$ & 1.10 & $<0.001$ & $<0.001$ & $<0.001$ \\
\hline Propionic acid (g/kg DM) & $1.30^{\mathrm{a}}$ & $0.86^{b}$ & $0.68^{c}$ & $0.65^{\mathrm{cd}}$ & $0.89^{b}$ & $0.57^{e}$ & $0.59^{\text {de }}$ & $0.59^{\text {de }}$ & 0.05 & $<0.001$ & $<0.001$ & $<0.001$ \\
\hline Butyric acid (g/kg DM) & $12.3^{\mathrm{a}}$ & $4.24^{b}$ & $4.57^{\mathrm{b}}$ & $3.76^{\mathrm{c}}$ & $4.24^{b}$ & $2.20^{d}$ & $1.89^{d}$ & $1.01^{\mathrm{e}}$ & 0.68 & $<0.001$ & $<0.001$ & $<0.001$ \\
\hline $\begin{array}{l}\text { Water soluble carbohydrate } \\
\qquad(\mathrm{g} / \mathrm{kg} \mathrm{DM})\end{array}$ & $12.1^{d}$ & $18.1^{\mathrm{a}}$ & $13.2^{c}$ & $17.2^{b}$ & $9.13^{f}$ & $13.1^{c}$ & $11.3^{\mathrm{e}}$ & $13.0^{c}$ & 0.58 & $<0.001$ & $<0.001$ & 0.002 \\
\hline $\mathrm{NH}_{3}-\mathrm{N}(\mathrm{g} / \mathrm{kg} \mathrm{TN})$ & $133^{a}$ & $74.6^{c}$ & $60.3^{e}$ & $65.5^{d}$ & $94.2^{b}$ & $65.6^{d}$ & $40.2^{f}$ & $41.6^{f}$ & 5.91 & $<0.001$ & $<0.001$ & $<0.001$ \\
\hline $\begin{array}{l}\text { Lactic acid bacteria } \\
\quad\left(\log _{10} \mathrm{CFU} / \mathrm{g} \mathrm{FM}\right)\end{array}$ & $4.58^{9}$ & $6.13^{e}$ & $6.18^{e}$ & $7.38^{\circ}$ & $5.11^{f}$ & $6.54^{d}$ & $7.77^{b}$ & $8.56^{\mathrm{a}}$ & 0.26 & $<0.001$ & $<0.001$ & $<0.001$ \\
\hline $\begin{array}{l}\text { Aerobic bacteria } \\
\quad\left(\log _{10} \mathrm{CFU} / \mathrm{g} F \mathrm{FM}\right)\end{array}$ & $3.20^{\mathrm{b}}$ & $2.19^{f}$ & $2.42^{\mathrm{e}}$ & $2.58^{d}$ & $3.49^{\mathrm{a}}$ & $3.15^{b}$ & $2.88^{c}$ & $2.57^{d}$ & 0.09 & $<0.001$ & $<0.001$ & $<0.001$ \\
\hline Yeasts $\left(\log _{10}\right.$ CFU/g FM) & $5.06^{\mathrm{ab}}$ & $4.33^{b}$ & $4.58^{\mathrm{ab}}$ & $4.49^{\mathrm{ab}}$ & $4.90^{\mathrm{ab}}$ & $5.30^{\mathrm{a}}$ & $4.81^{\mathrm{ab}}$ & $4.49^{\mathrm{ab}}$ & 0.10 & 0.152 & 0.280 & 0.150 \\
\hline Moulds $\left(\log _{10}\right.$ CFU/g FM) & $4.18^{\mathrm{a}}$ & $2.71^{\mathrm{cd}}$ & $2.24^{d}$ & $3.49^{\mathrm{abc}}$ & $3.89^{\mathrm{ab}}$ & $3.08^{\mathrm{bcd}}$ & $2.90^{\mathrm{bcd}}$ & $2.70^{\mathrm{cd}}$ & 0.16 & 0.961 & 0.003 & 0.158 \\
\hline V-score & $27^{9}$ & $55^{\mathrm{e}}$ & $56^{\mathrm{e}}$ & $63^{d}$ & $51^{f}$ & $75^{\mathrm{c}}$ & $82^{b}$ & $89^{\mathrm{a}}$ & 3.88 & $<0.001$ & $<0.001$ & 0.001 \\
\hline
\end{tabular}

SEM, standard error of the mean; DM, dry matter; $\mathrm{NH}_{3}-\mathrm{N}$, ammonia nitrogen; TN, total nitrogen; $\mathrm{CFU}$, colony-forming units; $\mathrm{FM}$, fresh matter.

1) $\mathrm{CK}$, control; M, molasses; LP, L. plantarum, M+LP, molasses+L. plantarum.

${ }^{a-g}$ Means within the same row with different superscripts differ significantly from each other $(p<0.05)$.

control of the fresh, all the silages were fermented, with the $\mathrm{V}$-score in all treatments ranging from 51 to 89 after 60 days of ensiling. The M+LP treatment at wilted exhibited significantly increased LA content and V-score and decreased $\mathrm{pH}$ and $\mathrm{BA}$ values compared to the other treatments.

The chemical composition of the silages is listed in Table 3. After silage, the DM, DM recovery, ADF, and ash levels were higher at wilted than fresh. The NDF of the wiltedtreated was not significantly different from that of the freshtreated. The additive-treated groups had lower ADF levels than the control in the wilted-treated $(p<0.05)$, however, there was no significant difference of effects of wilted, additives and interaction between wilted and the additives on
CP. The interaction between wilted and the additives was significant for $\mathrm{EE}(\mathrm{p}<0.001)$, ash $(\mathrm{p}<0.001)$ and non-fibrous carbohydrate $(\mathrm{NFC})(\mathrm{p}=0.013)$. At fresh, after silage-treated had lower DM and CP contents and higher NFC than the before silage, there was no significant difference for NDF before and after the fermentation of silage. At wilted, after ensiling had lower DM contents and higher NFC than before ensiling, in contrast, there was no significance difference of $\mathrm{CP}$ before and after ensiling.

\section{In vitro gas production}

The GP profiles of the sudangrass silages are presented in Figure 1. Significant differences were observed among treat-

Table 3. Chemical composition of sudangrass silages after 60 days of ensiling

\begin{tabular}{|c|c|c|c|c|c|c|c|c|c|c|c|c|}
\hline \multirow{3}{*}{ Items } & \multicolumn{8}{|c|}{ Treatments $^{1)}$} & \multirow{3}{*}{ SEM } & \multirow{2}{*}{\multicolumn{3}{|c|}{ p-value }} \\
\hline & \multicolumn{4}{|c|}{ Fresh } & \multicolumn{4}{|c|}{ Wilted } & & & & \\
\hline & CK & $\mathbf{M}$ & LP & M+LP & CK & $\mathbf{M}$ & LP & $M+L P$ & & Wilted & Additives & $\begin{array}{c}\text { Wilted } \\
\text { xadditives }\end{array}$ \\
\hline Dry matter (g/kg FW) & $193^{\text {cd }}$ & $196^{\circ}$ & $194^{d}$ & $191^{d}$ & $289^{a}$ & $286^{a}$ & $283^{a b}$ & $281^{b}$ & 9.83 & $<0.001$ & 0.753 & 0.638 \\
\hline Dry matter recovery (\%) & $94.7^{\circ}$ & $94.6^{\mathrm{c}}$ & $94.3^{\mathrm{C}}$ & $93.5^{\mathrm{c}}$ & $99.3^{a}$ & $98.1^{\mathrm{ab}}$ & $98.0^{\mathrm{ab}}$ & $97.1^{b}$ & 0.45 & $<0.001$ & 0.233 & 0.090 \\
\hline Crude protein (g/kg DM) & 111 & 109 & 108 & 114 & 108 & 107 & 113 & 113 & 0.92 & 0.817 & 0.189 & 0.365 \\
\hline Neutral detergent fibre (g/kg DM) & $638^{\circ}$ & $647^{a b}$ & $640^{\mathrm{bc}}$ & $635^{c}$ & $637^{c}$ & $643^{a b c}$ & $648^{a}$ & $637^{c}$ & 1.17 & 0.544 & 0.002 & 0.087 \\
\hline Acid detergent fibre (g/kg DM) & $356^{\text {cde }}$ & $353^{\text {de }}$ & $355^{\text {cde }}$ & $347^{e}$ & $375^{a}$ & $367^{\mathrm{ab}}$ & $365^{\mathrm{bc}}$ & $362^{\text {bcd }}$ & 2.02 & $<0.001$ & 0.023 & 0.549 \\
\hline Ether extract (g/kg DM) & $25.1^{\text {cd }}$ & $29.4^{\mathrm{a}}$ & $26.0^{\mathrm{cd}}$ & $24.8^{d}$ & $29.3^{a}$ & $25.4^{\text {cd }}$ & $27.4^{b}$ & $26.2^{\mathrm{bc}}$ & 0.38 & 0.022 & 0.001 & $<0.001$ \\
\hline Ash (g/kg DM) & $65.6^{c}$ & $65.6^{c}$ & $65.1^{c}$ & $59.5^{d}$ & $70.9^{\mathrm{a}}$ & $69.1^{b}$ & $71.4^{\mathrm{a}}$ & $71.4^{\mathrm{a}}$ & 0.82 & $<0.001$ & $<0.001$ & $<0.001$ \\
\hline $\mathrm{NFC}(\mathrm{g} / \mathrm{kg} \mathrm{DM})$ & $226^{a}$ & $214^{\mathrm{bc}}$ & $226^{a}$ & $226^{a}$ & $227^{a}$ & $225^{a}$ & $212^{c}$ & $224^{\mathrm{ab}}$ & 1.49 & 0.596 & 0.106 & 0.013 \\
\hline
\end{tabular}

SEM, standard error of the mean; FW, fresh weight; DM, dry matter; NFC, non-fibrous carbohydrate.

1) $\mathrm{CK}$, control; $\mathrm{M}$, molasses; LP, L. plantarum, M+LP, molasses+L. plantarum.

${ }^{a-e}$ Means within the same row with different superscripts differ significantly from each other $(p<0.05)$ 


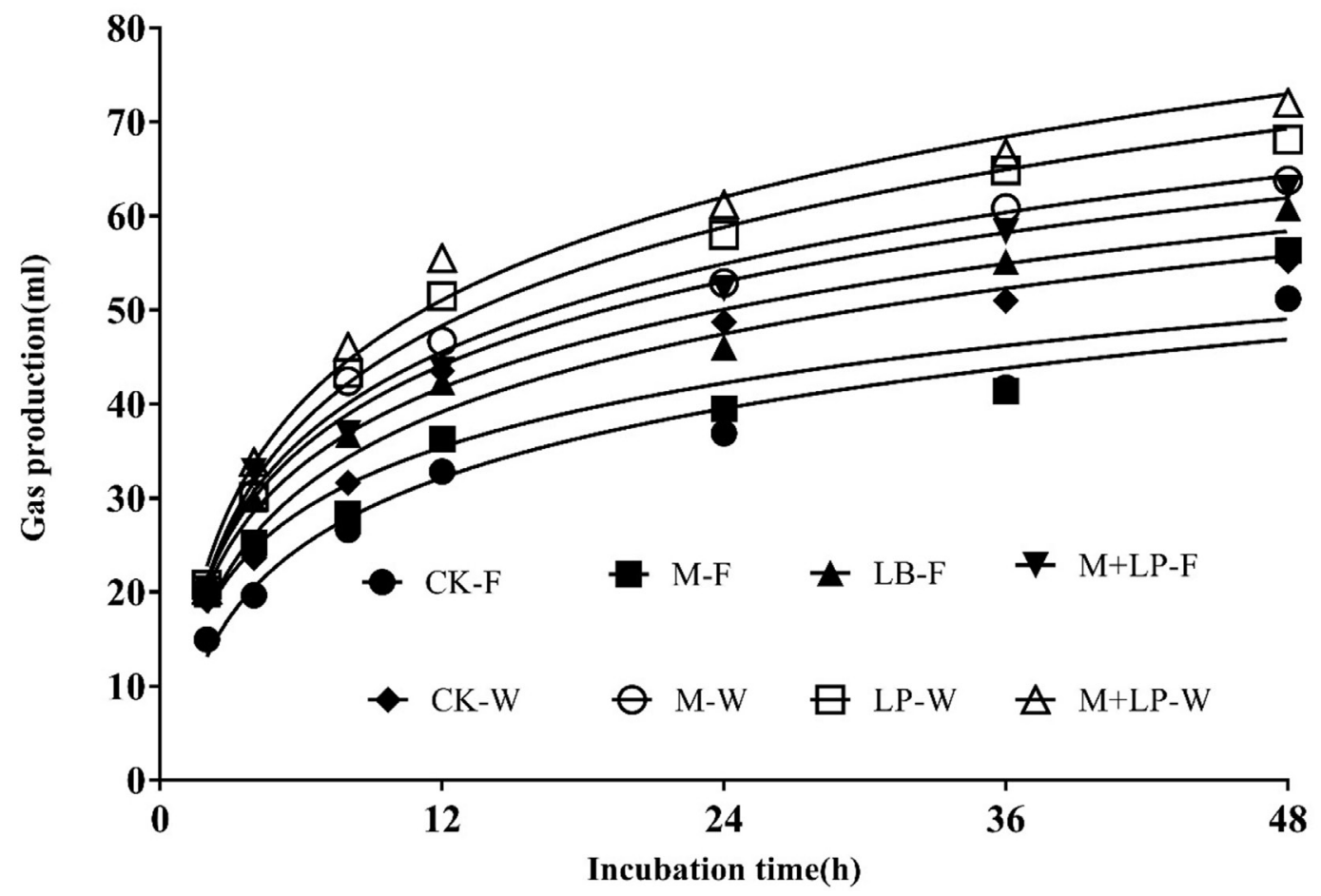

Figure 1. Gas production profiles from in vitro fermentation of sudangrass silages for $48 \mathrm{~h}$. C-F = control-Fresh; M-F = molasses-Fresh; LP-F = $L$. plantarum-Fresh; $\mathrm{M}+\mathrm{LP}-\mathrm{F}=$ molasses+L. plantarum-Fresh; $\mathrm{C}-\mathrm{W}=$ control-Wilted; $\mathrm{M}-\mathrm{W}=$ molasses-Wilted; $\mathrm{LP}-\mathrm{W}=\mathrm{L}$. plantarum-Wilted; $\mathrm{M}+\mathrm{LP}-\mathrm{F}=$ molasses $+L$. plantarum-Wilted.

ments in terms of gas volume. As shown in Table 4, the IVADFD values were higher in additive-treated silages than in the control. Significant interactions were observed between wilted and additives in terms of in vitro GP $(\mathrm{p}<0.001)$ at $48 \mathrm{~h}$ of incubation. In the Kinetic PG model, significant interactions were observed between wilted and additives of the asymptotic GP (A) $(\mathrm{p}<0.001)$, GP rate $(\mathrm{p}=0.005)$, half time $(\mathrm{p}<0.001)$ and AGPR $(\mathrm{p}<0.001)$, however, there was no effect on lag time ( $\mathrm{p}=0.341)$. The total 48 -h GP was increased by supplementation with additives and was higher than in

Table 4. In vitro rumen digestibility and gas production kinetics in culture fluids after $48 \mathrm{~h}$ incubation with different moisture content and additives of sudangrass silage

\begin{tabular}{|c|c|c|c|c|c|c|c|c|c|c|c|c|}
\hline \multirow{3}{*}{ Items } & \multicolumn{8}{|c|}{ Treatments ${ }^{1)}$} & \multirow{3}{*}{ SEM } & \multirow{2}{*}{\multicolumn{3}{|c|}{ p-value }} \\
\hline & \multicolumn{4}{|c|}{ Fresh } & \multicolumn{4}{|c|}{ Wilted } & & & & \\
\hline & CK & M & LP & $M+L P$ & CK & M & LP & $M+L P$ & & Wilted & Additives & $\begin{array}{c}\text { Wilted } \\
\text { xadditives }\end{array}$ \\
\hline IVDMD & $0.64^{e}$ & $0.65^{\text {de }}$ & $0.67^{\mathrm{cd}}$ & $0.66^{\text {cde }}$ & $0.66^{\text {cde }}$ & $0.69^{b c}$ & $0.70^{b}$ & $0.73^{\mathrm{a}}$ & 0.01 & $<0.001$ & 0.001 & 0.124 \\
\hline IVCPD & $0.62^{b c}$ & $0.60^{\text {cd }}$ & $0.61^{\mathrm{bcd}}$ & $0.64^{\mathrm{ab}}$ & $0.59^{d}$ & $0.61^{\text {cd }}$ & $0.65^{\mathrm{a}}$ & $0.65^{\mathrm{a}}$ & 0.01 & 0.351 & $<0.001$ & 0.007 \\
\hline IVNDFD & $0.51^{d}$ & $0.61^{a}$ & $0.56^{\mathrm{bc}}$ & $0.54^{c}$ & $0.60^{\mathrm{a}}$ & $0.54^{c}$ & $0.58^{\mathrm{ab}}$ & $0.60^{a}$ & 0.01 & 0.003 & 0.199 & $<0.001$ \\
\hline IVADFD & $0.29^{e}$ & $0.36^{\mathrm{abc}}$ & $0.37^{\mathrm{ab}}$ & $0.38^{a}$ & $0.29^{e}$ & $0.33^{\text {cd }}$ & $0.31^{\text {de }}$ & $0.34^{\mathrm{bcd}}$ & 0.01 & $<0.001$ & $<0.001$ & 0.085 \\
\hline Gas production (mL/g DM) & $51.2^{f}$ & $56.5^{e}$ & $61.0^{d}$ & $63.1^{\mathrm{c}}$ & $55.4^{e}$ & $63.7^{c}$ & $68.4^{b}$ & $72.0^{\mathrm{a}}$ & 1.35 & $<0.001$ & $<0.001$ & $<0.001$ \\
\hline \multicolumn{13}{|l|}{ Gas production kinetic } \\
\hline$A(m L)$ & $51.2^{f}$ & $56.3^{e}$ & $60.8^{d}$ & $62.9^{c}$ & $55.2^{e}$ & $64.1^{c}$ & $68.2^{b}$ & $72.1^{\mathrm{a}}$ & 1.36 & $<0.001$ & $<0.001$ & $<0.001$ \\
\hline Gas production rate $(/ \mathrm{h})$ & $0.26^{f}$ & $0.29^{e}$ & $0.32^{d}$ & $0.33^{c}$ & $0.29^{e}$ & $0.33^{\mathrm{c}}$ & $0.36^{b}$ & $0.38^{\mathrm{a}}$ & 0.01 & $<0.001$ & $<0.001$ & 0.005 \\
\hline $\operatorname{Lag}(h)$ & 0 & -0.01 & 0.01 & -0.01 & -0.02 & 0.01 & 0.01 & 0.01 & 0.00 & 0.681 & 0.254 & 0.341 \\
\hline Half time (h) & $4.58^{b}$ & $2.95^{f}$ & $3.84^{d}$ & $3.57^{e}$ & $5.10^{\mathrm{a}}$ & $4.04^{c}$ & $4.14^{c}$ & $2.58^{\mathrm{g}}$ & 0.16 & $<0.001$ & $<0.001$ & $<0.001$ \\
\hline $\operatorname{AGPR}(\mathrm{mL} / \mathrm{h})$ & $9.77^{f}$ & $12.0^{\mathrm{e}}$ & $13.9^{d}$ & $15.0^{c}$ & $12.0^{\mathrm{e}}$ & $15.4^{c}$ & $17.7^{\mathrm{b}}$ & $19.5^{\mathrm{a}}$ & 0.63 & $<0.001$ & $<0.001$ & $<0.001$ \\
\hline
\end{tabular}

SEM, standard error of the mean; IVDMD, in vitro dry matter digestibility; IVCPD, in vitro crude protein digestibility; IVNDFD, in vitro neutral detergent fibre digestibility; IVADFD, in vitro acid detergent fibre digestibility; DM, dry matter; A, the asymptotic gas production; Lag, the initial delay time in the onset of gas production; AGPR, the average gas production rate.

${ }^{1)} \mathrm{CK}$, control; M, molasses; LP, L. plantarum, M+LP, molasses+L. plantarum.

${ }^{a-g}$ Means within the same row with different superscripts differ significantly from each other $(p<0.05)$. 
the control. The estimated values for A were in highest for the $\mathrm{M}+\mathrm{LP}$ silage at wilted.

The $\mathrm{NH}_{3}-\mathrm{N}$, NGR, and total VFA levels were affected by wilted, the additives and the interaction of wilted with the additives ( $p<0.05$; Table 5$)$. The total VFA content in the additive treatments was higher than that in the control. All the additive treatments decreased the $\mathrm{pH}$ levels compared to the control. The highest total VFA content $(115 \mathrm{mmol} / \mathrm{L})$ was observed in the LP treatment at wilted. The interaction between wilted and the additives affected the VFA pattern, including the concentrations of acetate $(\mathrm{p}=0.023)$, propionate $(\mathrm{p}<0.001)$, butyrate $(\mathrm{p}<0.001)$, isobutyrate $(\mathrm{p}=0.022)$, valerate $(\mathrm{p}<0.001)$, and isovalerate $(\mathrm{p}<0.001)$.

\section{DISCUSSION}

\section{Chemical and microbial compositions of materials before ensiling}

The most significant change of forage chemical composition caused by wilting is to reduce the water content. Low water content can effectively inhibit the fermentation of clostridium, to improve the smell of silage and effectively inhibit the occurrence of mildew. The DM content of grass strongly influences the rate and extent of ensiling. Grasses with a low DM and sugar levels at pre-ensiling may exhibit clostridial fermentation and subsequent poor acceptance of the silage by animals [18]. McDonald wrote that wilting can increase the content of the DM and WSC [7], however, similar results were not observed in this experiment. This may be due to the high lignification of the sudangrass stalk, which is difficult to break during processing, and with the loss of the water the content of WSC will also decreased. According to McDonald [7], a material can be considered to be successfully ensiled if it exhibits favorable DM levels (280 to $340 \mathrm{~g} / \mathrm{kg} \mathrm{DM}$ ), fermentable sugar concentrations ranging from 30 to $50 \mathrm{~g} / \mathrm{kg}$ $\mathrm{DM}$, a low $\mathrm{BC}$ and LAB abundances greater than $1 \times 10^{5} \mathrm{CFU} /$ $\mathrm{g}$ FM. In this study, the DM of the sudangrass in fresh before ensiling was lower than this standard, suggesting that it might be difficult to obtain high-quality silage by direct ensiling of sudangrass.

\section{Fermentation quality of sudangrass silages}

Silage $\mathrm{pH}$ is one of the main factors that influences the extent of fermentation and ensiling quality [19]. The low final $\mathrm{pH}$ (4.70 or less) in the wilted and additive-treated sudangrass silages suggested the recommended standard for highquality silage (4.30 to 4.70) [20]. As expected, wilted sudangrass silage supplemented with $L$. plantarum improved the LA levels under the increased the microorganism concentration. After wilting, the sudangrass silages supplemented with additives were all well preserved and exhibited moderate fermentation quality, despite the low WSC content and numbers of epiphytic LAB in the initial herbage. The fermentation of the wilted silage exhibited a higher target ensiling DM due to elevated total VFA and LA concentrations. The ensiling quality at wilted is usually better than that fresh [21], which is consistent with the results of this study. The presence of BA in silage is undesirable given that its generation is an energy-waste metabolism and $\mathrm{BA}>5 \mathrm{~g} / \mathrm{kg} \mathrm{DM}$ is an indicator of substantial clostridial activity reducing feed intake and causing health issues [22]. In the present study, the high BA content $(12.3 \mathrm{~g} / \mathrm{kg} \mathrm{DM})$ indicated extensive clostridial fermentation in control-treated fresh silage. Wilting and additives could help to inhibit the activity of undesirable organisms in silage. It is supported by the decrease of BA content, where BA were not higher than $5 \mathrm{~g} / \mathrm{kg} \mathrm{DM}$ in

Table 5. In vitro ruminal fermentation characteristics with different moisture content and additives of sudangrass silage

\begin{tabular}{|c|c|c|c|c|c|c|c|c|c|c|c|c|}
\hline \multirow{3}{*}{ Items } & \multicolumn{8}{|c|}{ Treatments ${ }^{1)}$} & \multirow{3}{*}{ SEM } & \multirow{2}{*}{\multicolumn{3}{|c|}{$\mathrm{p}$-value }} \\
\hline & \multicolumn{4}{|c|}{ Fresh } & \multicolumn{4}{|c|}{ Wilted } & & & & \\
\hline & CK & M & LP & $M+L P$ & CK & M & LP & $M+L P$ & & Wilted & Additives & $\begin{array}{c}\text { Wilted } \\
\text { xadditives }\end{array}$ \\
\hline $\mathrm{pH}$ & $6.81^{\mathrm{a}}$ & $6.79^{\mathrm{ab}}$ & $6.78^{\mathrm{ab}}$ & $6.74^{\mathrm{bc}}$ & $6.78^{\mathrm{ab}}$ & $6.77^{\mathrm{ab}}$ & $6.74^{\mathrm{bc}}$ & $6.70^{c}$ & 0.01 & 0.008 & 0.002 & 0.732 \\
\hline $\mathrm{NH}_{3}-\mathrm{N}(\mathrm{mmol} / \mathrm{L})$ & $11.4^{\mathrm{b}}$ & $10.5^{c}$ & $10.2^{\text {cd }}$ & $10.3^{\mathrm{cd}}$ & $10.1^{d}$ & $11.2^{b}$ & $12.2^{\mathrm{a}}$ & $10.3^{\mathrm{cd}}$ & 0.15 & $<0.001$ & $<0.001$ & $<0.001$ \\
\hline NGR & $5.13^{\mathrm{a}}$ & $4.92^{\mathrm{a}}$ & $5.15^{\mathrm{a}}$ & $4.52^{b}$ & $4.58^{b}$ & $4.12^{c}$ & $4.06^{c}$ & $4.47^{\mathrm{b}}$ & 0.08 & $<0.001$ & 0.001 & $<0.001$ \\
\hline Acetate & $67.3^{d}$ & $69.5^{c}$ & $69.4^{c}$ & $72.5^{b}$ & $69.3^{c}$ & $69.0^{c}$ & $71.5^{\mathrm{b}}$ & $75.3^{a}$ & 0.51 & $<0.001$ & $<0.001$ & 0.023 \\
\hline Propionate & $15.3^{\mathrm{e}}$ & $16.6^{d}$ & $16.9^{d}$ & $18.6^{\mathrm{c}}$ & $18.1^{\mathrm{c}}$ & $18.1^{\mathrm{c}}$ & $20.9^{b}$ & $22.2^{a}$ & 0.45 & $<0.001$ & $<0.001$ & $<0.001$ \\
\hline Butyrate & $8.91^{\mathrm{e}}$ & $9.24^{d}$ & $9.96^{\mathrm{bc}}$ & $10.2^{\mathrm{abc}}$ & $8.56^{f}$ & $9.91^{\mathrm{C}}$ & $10.3^{\mathrm{ab}}$ & $10.4^{\mathrm{a}}$ & 0.14 & 0.011 & $<0.001$ & $<0.001$ \\
\hline Isobutyrate & $1.82^{\mathrm{bc}}$ & $1.70^{\mathrm{cd}}$ & $1.93^{\mathrm{ab}}$ & $1.41^{\mathrm{e}}$ & $2.07^{\mathrm{a}}$ & $1.94^{\mathrm{ab}}$ & $1.87^{\mathrm{b}}$ & $1.61^{d}$ & 0.04 & $<0.001$ & $<0.001$ & 0.022 \\
\hline Valerate & $1.68^{c}$ & $1.58^{d}$ & $1.48^{\mathrm{e}}$ & $1.44^{e}$ & $1.77^{\mathrm{bc}}$ & $1.85^{b}$ & $2.00^{a}$ & $1.52^{\text {de }}$ & 0.04 & $<0.001$ & $<0.001$ & $<0.001$ \\
\hline
\end{tabular}

SEM, standard error of the mean; NGR, ratio of non-glucogenic to glucogenic acids; VFA, volatile fatty acids.

${ }^{1)} \mathrm{CK}$, control; $\mathrm{M}$, molasses; $\mathrm{LP}$, L. plantarum, $\mathrm{M}+\mathrm{LP}$, molasses+L. plantarum.

${ }^{a-f}$ Means within the same row with different superscripts differ significantly from each other $(p<0.05)$. 
those treatments. In addition, wilting and L. plantarum can reduce the content of $\mathrm{AA}$ and $\mathrm{BA}$, which can improve palatability of the silage. Similar results have been reported by Zhang et al [23], who found wilting and L. plantarum decreased AA and BA contents of mulberry silage.

$\mathrm{NH}_{3}-\mathrm{N}$ production reflects the extent of proteolysis in silage. Well-preserved silages should have less than $100 \mathrm{~g} / \mathrm{kg}$ TN [22]. In the present study, the value of $\mathrm{NH}_{3}-\mathrm{N}$ was less than $94.2 \mathrm{~g} / \mathrm{kg}$ TN at wilted treatment, indicating that extensive proteolysis may not have occurred. Microorganisms exhibit proteolytic activity mainly in low-DM silages at high $\mathrm{pH}$ values (i.e., >4.2) when the growth and activity of the microorganisms is not totally inhibited under such conditions [7], which may partly explain why the $\mathrm{NH}_{3}-\mathrm{N}$ levels were lower at wilted than fresh (higher DM and lower $\mathrm{pH}$ values were observed at wilted than fresh).

Molasses and the LAB inoculants used in this study are commonly used to improve the fermentation quality of sudangrass silage. Furthermore, the increased LAB counts and decreased mould counts after supplementation with additives suggest that high-quality silage was obtained, which might considerably improve the dry matter intake (DMI) of ruminants. It is well known that adequate WSC levels and LAB counts are important for rapid establishment and growth of LAB. Molasses were added to provide the WSC levels necessary for ensiling fermentation. Microbial inoculation, especially of homofermentative $\mathrm{LAB}$, is a common practice for acceleration of fermentation, resulting in high-quality silage and reduced DM loss. Adesogan et al [24] found that addition of exogenous L. plantarum accelerated homofermentation, allowing increased production of LA by L. plantarum. Thus, the increased LA content in the M+LP treatment at wilted might be attributed mainly to using molasses together with L. plantarum, which improved the WSC and LAB content before ensiling. Muck et al [25] concluded that microbial inoculation lowered the $\mathrm{pH}$ and improved the LA content, and Jahanzad et al [26] confirmed that molasses can enhance the activity of homofermentative bacteria, which convert WSC to LA in millet and soybean silage. L. plantarum, used for inoculation in this study, is a homofermentative lactobacillus that can ferment a wide variety of substrates and rapidly produce large amounts of lactic acid. L. plantarum had positive effects on grass silage fermentation characteristics by lowering the $\mathrm{pH}$ and shifting fermentation towards LA, which is consistent with the results of this study.

From a practical standpoint, wilting can reduce risk and increase DM levels during ensiling, which can be used to improve silage quality. The results in this study demonstrated that wilting is an effective measure.

\section{In vitro gas production}

In vitro GP is associated with the availability of NFC and fer- mentable carbohydrate content from the substrate. Evaluation of in vitro GP is also an indicator of rumen digestion, as in vitro GP affects the rumen passage rate and DMI. In this study, the IVDMD was higher in M+LP treatment at wilted than in other groups, which might be attributed to the decreased DM loss in silage after supplementation with molasses and L. plantarum. Thus, the IVDMD of the rumen was elevated. Additionally, the M+LP treatment at wilted provided and preserved the WSC and LA content in silage, which further benefited in vitro rumen degradation. In the present study, the potential GP, A and GP rates of additive-treated silages were higher than those of the control, probably due to the additive-treated reduced loss of nutrients after additive supplementation.

GP has been reported to be positively correlated with VFA production. The total VFA concentrations were significant difference between the control and the M+LP-treated silage at wilted at $48 \mathrm{~h}$ of fermentation. GP is a direct result of microbial degradation of feed and an indirect result of the buffering of acids generated by fermentation [27]. Moreover, additional gas is produced simply by contact between acids (VFAs and LA) produced in the silo and the buffer inoculum. Therefore, indirect GP from acids produced in the jars and during in vitro fermentation might explain the positive relationship between GP and VFA concentration in the present study.

The total VFA is one of the main energy sources for ruminant growth and development, which provides about $70 \%$ to $80 \%$ of the energy required by ruminants [28]. Although the composition and concentration of VFA in rumen were affected by feed concentrate/roughage ratio, processing method and additives, the highest content of VFA in rumen was the acetate [29]. The present study had similar results, which supports the previous studies. The VFA pattern of in vitro rumen fermentation was affected by wilted, the additives and the interactions between wilted and the additives in the present study. In vitro ruminal fermentation, the treatment after wilting and additives, affected the contents of AA, PA, and BA so that they were increased in comparison with the control. It could be explained that wilting and additives can improve the fermentation quality of sudangrass silage, especially the content of lactic acid, which can be degraded into acetate, propionate, and butyrate [30]. Thus, the VFA content of the rumen was elevated.

\section{CONCLUSION}

It was concluded that wilting and supplementation with molasses and L. plantarum affected the ensiling quality and in vitro ruminal fermentation characteristics of sudangrass silage. In comparison with sudangrass before ensiling, after ensiling had lower DM and higher NFC. Supplementation with mo- 
lasses and L. plantarum prevented accumulation of BA and resulted in increased homolactic acid fermentation. The in vitro rumen digestibility of silage can be regulated by wilted and additive treatment. The best treatment for sudangrass silage was $\mathrm{M}+\mathrm{LP}$ at wilted, based on ensiling quality and in vitro ruminal fermentation characteristics.

\section{CONFLICT OF INTEREST}

We certify that there is no conflict of interest with any financial organization regarding the material discussed in the manuscript.

\section{ACKNOWLEDGMENTS}

This work was financially supported by the National Forage Industry System (CARS-34), Grassology Peak Discipline Foundation of Xinjiang Uygur Autonomous Region, China; the Key Research and Development Program in Ningxia Hui Autonomous Region (2017BY082), the Agricultural Technology Test demonstration and Service Support Program in China (131821301064071005), the Natural Science Foundation of Xinjiang of China (2017D01B19), and the Scientific Research Program of the Higher Education Institution of Xinjiang of China (XJEDU2016S049); National Key R\&D Program of China (2017YFE0109200).

\section{REFERENCES}

1. Kondo M, Kita K, Yokota H. Effects of tea leaf waste of green tea, oolong tea, and black tea addition on sudangrass silage quality and in vitro gas production. J Sci Food Agric 2004;84: 721-7. https://doi.org/10.1002/jsfa.1718

2. Guo G, Yu CQ, Wang Q, Xin PC, Shimojo M, Shao T. Silage fermentation characteristics of Italian ryegrass (Lolium multiflorum Lam.) harvested at various times on a sunny day. Crop Sci 2014;54:851-8. https://doi.org/10.2135/cropsci2012.12. 0692

3. Zhang XQ, Jin YM, Zhang YJ, Yu Z, Yan WH. Silage quality and preservation of Urtica cannabina ensiled alone and with additive treatment. Grass Forage Sci 2014;69:405-14. https://doi.org/10.1111/gfs.12036

4. Kang S, Wanapat M, Nunoi A. Effect of urea and molasses supplementation on quality of cassava top silage. J Anim Feed Sci 2018;27:74-80. http://doi.org/10.22358/jafs/85544/2018

5. Contreras-Govea FE, Muck RE, Broderick GA, Weimer PJ. Lactobacillus plantarum effects on silage fermentation and in vitro microbial yield. Anim Feed Sci Technol 2013;179:618. https://doi.org/10.1016/j.anifeedsci.2012.11.008

6. Ellis JL, Bannink A, Hindrichsen IK, et al. The effect of lactic acid bacteria included as a probiotic or silage inoculant on in vitro rumen digestibility, total gas and methane production.
Anim Feed Sci Technol 2016;211:61-74. https://doi.org/10. 1016/j.anifeedsci.2015.10.016

7. McDonald P. The biochemistry of silage. Chichester, UK: John Wiley \& Sons, Ltd.; 1981.

8. Owens VN, Albrecht KA, Muck RE. Protein degradation and ensiling characteristics of red clover and alfalfa wilted under varying levels of shade. Can J Plant Sci 1999;79:20922. https://doi.org/10.4141/P98-034

9. Mertens DR. Gravimetric determination of amylase-treated neutral detergent fiber in feeds with refluxing in beakers or crucibles: collaborative study. J AOAC Int 2002;85:1217-40.

10. Baur FJ, Ensminger LG. The Association of Official Analytical Chemists (AOAC). J Am Oil Chem Soc 1977;54:171-2. https:// doi.org/10.1007/BF02670789

11. Playne MJ, McDonald P. The buffering constituents of herbage and of silage. J Sci Food Agric 1966;17:264-8. https://doi.org/ 10.1002/jsfa.2740170609

12. Murphy RP. A method for the extraction of plant samples and the determination of total soluble carbohydrates. J Sci Food Agric 1958;9:714-7. https://doi.org/10.1002/jsfa.274 0091104

13. Broderick GA, Kang JH. Automated simultaneous determination of ammonia and total amino acids in ruminal fluid and in vitro media 1. J Dairy Sci 1980;63:64-75. https://doi. org/10.3168/jds.S0022-0302(80)82888-8

14. Takahashi T, Horiguchi K, Goto M. Effect of crushing unhulled rice and the addition of fermented juice of epiphytic lactic acid bacteria on the fermentation quality of whole crop rice silage, and its digestibility and rumen fermentation status in sheep. Anim Sci J 2005;76:353-8. https://doi.org/10.1111/ j.1740-0929.2005.00275.x

15. France J, Dijkstra J, Dhanoa MS, Lopez S, Bannink A. Estimating the extent of degradation of ruminant feeds from a description of their gas production profiles observed in vitro: derivation of models and other mathematical considerations. Br J Nutr 2000;83:143-50. https://doi.org/10.1017/S000711 4500000180

16. Carro MD, Ranilla MJ, Tejido ML. Using an in vitro gas production technique to examine feed additives: effects of correcting values for different blanks. Anim Feed Sci Technol 2005;123:173-84. https://doi.org/10.1016/j.anifeedsci.2005. 04.045

17. Ørskov ER. Manipulation of rumen fermentation for maximum food utilization. In: Bourne GH, editor. World review of nutrition and dietetics. Basel, Switzerland: Karger; 1975. pp. 152-82. https://doi.org/10.1159/000397977

18. Nkosi BD, Meeske R, Van der Merwe HJ, Groenewald IB. Effects of homofermentative and heterofermentative bacterial silage inoculants on potato hash silage fermentation and digestibility in rams. Anim Feed Sci Technol 2010;157:195200. https://doi.org/10.1016/j.anifeedsci.2010.03.008

19. Denek N, Can A, Avci M, Aksu T, Durmaz H. The effect of 
molasses-based pre-fermented juice on the fermentation quality of first-cut lucerne silage. Grass Forage Sci 2011;66: 243-50. https://doi.org/10.1111/j.1365-2494.2011.00783.x

20. Kung L, Shaver RD, Grant RJ, Schmidt RJ. Silage review: interpretation of chemical, microbial, and organoleptic components of silages. J Dairy Sci 2018;101:4020-33. https:// doi.org/10.3168/jds.2017-13909

21. Li P, Tang H, Feng T, et al. Effects of UV radiation on the process of wilting and application of additives at ensiling on the fermentation quality of Siberian wildrye silage on the Qinghai-Tibetan plateau. Grassl Sci 2018;64:61-8. https://doi. org/10.1111/grs.12174

22. McDonald P, Edwards RA, Greenhalgh JFD, Morgan CA, Sinclair LA. Animal nutrition. Harlow, Essex, UK: Longman Scientific \& Technical; 1995.

23. Zhang YC, Wang XK, Li DX, Lin YL, Yang FY, Ni KK. Impact of wilting and additives on fermentation quality and carbohydrate composition of mulberry silage. Asian-Australas J Anim Sci 2020;33:254-63. https://doi.org/10.5713/ajas.18. 0925

24. Adesogan AT, Salawu MB. The effect of different additives on the fermentation quality, aerobic stability and in vitro digestibility of pea/wheat bi-crop silages containing contrasting pea to wheat ratios. Grass Forage Sci 2002;57:25-32. https:// doi.org/10.1046/j.1365-2494.2002.00298.x

25. Muck RE, Nadeau EMG, McAllister TA, Contreras-Govea FE, Santos MC, Kung L. Silage review: recent advances and future uses of silage additives. J Dairy Sci 2018;101:3980-4000. https://doi.org/10.3168/jds.2017-13839

26. Jahanzad E, Sadeghpour A, Hashemi M, Keshavarz Afshar R, Hosseini MB, Barker AV. Silage fermentation profile, chemical composition and economic evaluation of millet and soya bean grown in monocultures and as intercrops. Grass Forage Sci 2016;71:584-94. https://doi.org/10.1111/gfs.12216

27. Palmer MJA, Jessop NS, Fawcett R, Illius AW. Interference of indirect gas produced by grass silage fermentation acids in an in vitro gas production technique. Anim Feed Sci Technol 2005;123:185-96. https://doi.org/10.1016/j.anifeedsci. 2005.04.049

28. Silva LS, Bezerra LR, Silva AMA, Carneiro H, Moreira MN, Oliveira RL. In vitro degradation and gas production of glycerin generated in the biodiesel production chain. Acta Sci 2015;37:265-72. https://doi.org/10.4025/actascianimsci.v37i3. 27308

29. Muck RE, Filya I, Contreras-Govea FE. Inoculant effects on alfalfa silage: in vitro gas and volatile fatty acid production. J Dairy Sci 2007;90:5115-25. https://doi.org/10.3168/jds.2006878

30. Chen L, Guo G, Yuan XJ, Zhang J, Li JF, Shao T. Effects of applying molasses, lactic acid bacteria and propionic acid on fermentation quality, aerobic stability and in vitro gas production of total mixed ration silage prepared with oatcommon vetch intercrop on the Tibetan Plateau. J Sci Food Agric 2016;96:1678-85. https://doi.org/10.1002/jsfa.7271 